Meta

Journal des traducteurs

Translators' Journal

\title{
Visual Persuasion: Issues in the Translation of the Visual in Advertising
}

\section{Veronica Smith}

Volume 53, numéro 1, mars 2008

Le verbal, le visuel, le traducteur

The Verbal, the Visual, the Translator

URI : https://id.erudit.org/iderudit/017973ar

DOI : https://doi.org/10.7202/017973ar

Aller au sommaire du numéro

Éditeur(s)

Les Presses de l'Université de Montréal

ISSN

0026-0452 (imprimé)

1492-1421 (numérique)

Découvrir la revue

Citer cet article

Smith, V. (2008). Visual Persuasion: Issues in the Translation of the Visual in Advertising. Meta, 53(1), 44-61. https://doi.org/10.7202/017973ar
Résumé de l'article

Cette contribution cherche à décoder les messages de la publicité tout en posant la question de savoir comment ils sont accueillis par les représentants de quelques autres cultures. Répondre à cette question devient une tâche urgente lorsqu'on considère la fonction du traducteur dans l'adaptation de campagnes publicitaires mondiales. La plupart des annonceurs publicitaires cherchent à éviter des pièges linguistiques lorsqu'il s'agit d'adapter leur publicité aux besoins de nouveaux marchés, et pourtant la plupart des consommateurs se sentent attirés par les éléments non linguistiques, visuels de la publicité. On pourrait donc affirmer que le but principal du projet publicitaire consiste à activer les connotations visuelles dans la perception des consommateurs. À en croire Barthes, les images sont polysémiques, mais il n'est pas tout à fait clair que toutes les connotations présentes soient réalisées par les spectateurs des différentes cultures. Dans le domaine publicitaire, l'élément visuel s'oriente vers l'originalité et le stéréotype : pendant que la nouveauté attire l'attention, le stéréotype sert de point de repère à la perception conventionnelle. Les principales options du design qui sont discutées ici sont la mise en page et le choix de sujet qui permettent également d'encoder des options rhétoriques. Le décodage dépend de connaissances pragmatiques, culturelles et esthétiques. Le défi que le traducteur doit affronter consiste à décider si les stratégies et les connotations sous-jacentes à l'original peuvent être transposées telles quelles dans le nouveau contexte linguistique régi par des pratiques culturelles différentes. L’analyse présentée ici prend comme point de départ la sémiotique de Roland Barthes qu'elle combine avec des approches plus récentes issues des cultural studies. Elle est illustrée par des exemples qui caractérisent les stratégies des campagnes publicitaires mondiales et comprend une étude modèle de la publicité chinoise.
Ce document est protégé par la loi sur le droit d'auteur. L’utilisation des services d’Érudit (y compris la reproduction) est assujettie à sa politique d'utilisation que vous pouvez consulter en ligne.

https://apropos.erudit.org/fr/usagers/politique-dutilisation/ 


\title{
Visual Persuasion: Issues in the Translation of the Visual in Advertising
}

\author{
VERONICA SMITH \\ University of Klagenfurt, Klagenfurt, Austria \\ veronica.smith@uni-klu.ac.at
}

\section{RÉSUMÉ}

Cette contribution cherche à décoder les messages de la publicité tout en posant la question de savoir comment ils sont accueillis par les représentants de quelques autres cultures. Répondre à cette question devient une tâche urgente lorsqu'on considère la fonction du traducteur dans l'adaptation de campagnes publicitaires mondiales. La plupart des annonceurs publicitaires cherchent à éviter des pièges linguistiques lorsqu'il s'agit d'adapter leur publicité aux besoins de nouveaux marchés, et pourtant la plupart des consommateurs se sentent attirés par les éléments non linguistiques, visuels de la publicité. On pourrait donc affirmer que le but principal du projet publicitaire consiste à activer les connotations visuelles dans la perception des consommateurs. À en croire Barthes, les images sont polysémiques, mais il n'est pas tout à fait clair que toutes les connotations présentes soient réalisées par les spectateurs des différentes cultures. Dans le domaine publicitaire, l'élément visuel s'oriente vers l'originalité et le stéréotype: pendant que la nouveauté attire l'attention, le stéréotype sert de point de repère à la perception conventionnelle. Les principales options du design qui sont discutées ici sont la mise en page et le choix de sujet qui permettent également d'encoder des options rhétoriques. Le décodage dépend de connaissances pragmatiques, culturelles et esthétiques. Le défi que le traducteur doit affronter consiste à décider si les stratégies et les connotations sous-jacentes à l'original peuvent être transposées telles quelles dans le nouveau contexte linguistique régi par des pratiques culturelles différentes. L'analyse présentée ici prend comme point de départ la sémiotique de Roland Barthes qu'elle combine avec des approches plus récentes issues des cultural studies. Elle est illustrée par des exemples qui caractérisent les stratégies des campagnes publicitaires mondiales et comprend une étude modèle de la publicité chinoise.

\section{ABSTRACT}

This contribution is concerned with the decoding of advertising messages and the question of whether and how such messages are received by members of other cultures. The answers to these questions are important when considering the role of the translator in adapting global campaigns. Most advertisers concentrate on avoiding linguistic pitfalls when adapting advertisements for new markets, but in any advertisement, consumers are primarily attracted by visual elements. It can be said that an advertisement's potential for triggering a train of connotations in the consumers' minds is the most important aspect of advertisement design. According to Barthes, images are polysemous, but it is not clear whether all connotations are accessible to viewers in different cultures. The visual in advertising exploits the original and the stereotypical - novelty attracts attention, while the stereotypical serves as a reference to established knowledge. The main design options discussed are layout and directionality, as well as the choice of subject, which also allows a range of visual rhetorical options to be encoded. Decoding depends on practical, cultural and aesthetic knowledge. The challenge to the translator lies in assessing whether the choices made in the original advertisement and its connotation potential can be transferred to a new language market with different cultural practices. The analy- 
sis draws on the semiotics of Barthes, and presents more recent approaches from cultural studies. It is illustrated by examples of the strategies adopted for global advertising campaigns by companies operating world-wide and includes a case study on advertising in China.

\section{MOTS-CLÉS/KEYWORDS}

advertising, China, cross-cultural strategies, lifestyle marketing, visual design

\section{Introduction}

Any work on advertising should come with a sell-by-date. The advertising industry is engaged in a constant battle to attract the consumer's attention and a surprise attack, disrupting the analysts' orthodoxy, overturning whatever unwritten rules have been found useful for organising the disparate phenomena of advertising in the past, can happen at any time. With this disclaimer, I venture another analysis, in the hope it will not prove obsolete by the time it reaches the printed page.

The obvious candidate for the translator's attention in an advertisement is the language of the message, be it spoken or written. But many advertisements contain little or no verbal message, relying on visual messages of illustrations or the mental associations created in the viewers' minds as they scan the illustration. So is there a role for the translator in international advertising beyond coping with straight interlingual transfer? In this article I shall claim that the question can be answered with a cautious yes. It can be argued that Jakobson's category of intersemiotic translation, covering the transposition of verbal signs into non-verbal signs (Jakobson 2000: 114), should be extended to non-verbal transpositions of non-verbal sign systems, and that adaptations of advertisements for different cultural contexts, whether in terms of visual features or sound, fall into this category.

But caution is in order because there are conflicting views on the universality of associations aroused by advertising images. If some associations derive from common human experience, as, for example, anthropologists have found when analysing facial expressions in different cultures (Morris 1977), then there may be little need for intervention. Nor is there a consensus on whether international trade and the easy availability of goods from other countries mean that we no longer perceive many internationally available products as foreign. Although we encounter an apparent cultural convergence in many of the images of life and lifestyles represented in global advertisements, it is not clear whether this is a consumer-driven trend or a marketing convenience.

The study of visual features in advertising goes back to the middle of the last century. Particularly since the 1960s, the work of Roland Barthes has been an enduring source of insight in interpreting the visual in advertisements, but until recently little progress has been made in developing new frameworks to study the current diversity of advertising formats in terms of their multimodality and the interaction of different modes of communication. Kress and Jewitt hold the view that "meanings are made, distributed, interpreted and remade in interpretation through many representational and communicative modes - not just through language - whether as speech or as writing" (2003: 3, my emphases). This being the case, the visual components of an advertisement form an integral part of the whole message and cannot be ignored in translation (cf. Nord 1988, Schröder 1993). Kress and Van Leeuwen have 
recently established an "inventory of the elements and rules underlying a culturespecific form of visual communication" (1996: 3), which goes beyond semiotic analyses inspired by the work of Barthes. The role of the translator in rendering multimodal messages in a different target language and cultural frame, and the optimal timing of translator intervention in the marketing process, are, however, far from clear-cut, as the decision on whether an advertising campaign can be used in different markets is one that is normally made at the very outset of the planning process, well before text and image creation are considered.

Starting with a brief outline of marketing considerations, I shall outline elements of the decision-making process involved in developing an international advertising campaign. This will be followed by a survey of strategies for dealing with cross-cultural issues in global advertising, with examples from global campaigns. The next section introduces recent literature from the field of cultural studies, relating these insights to changing perceptions of advertising, and recently published work on visual design. A case study of advertising in China will be used to show where the fracture lines between Western and Asian advertising which are relevant for translation are to be found. Finally, there will be an assessment of the translator's role - its scope and limitations.

\section{Marketing Considerations}

Advertising may be the most overt sign of the marketing process for the consumer, but in fact it constitutes only a small part of what is known as the promotion mix. The promotion mix, along with the product, pricing and distribution mixes, is just one element of the marketing mix, and may not even include advertising as a part of the promotion. If marketing textbooks are anything to go by, language and cultural issues play a minimal role in the whole process, although they may ultimately be crucial for the acceptance of the product or service among consumers. The text-books tend to spend only a page or two on these issues, usually focusing on the faux-pas some companies have committed when language or cultural factors were neglected (cf. Séguinot 1994) and their product names or slogans inadvertently caused laughter or embarrassment, either in the original or in translation. Nevertheless there are indications that things are changing, that marketers are becoming increasingly aware that there is more to creating a global campaign than just avoiding the linguistic pitfalls that may negatively impact on the advertising message when cultural boundaries are crossed. Czinkota and Ronkainen, for example, offer the following sound advice to international marketers:

when translation is required [...] great care should be taken in selecting the translator. [...] To assess the quality of the translation, a complete evaluation with testing of the message's impact is necessary. In essence, this means that international marketers should never translate words but emotion (2001: 66).

De Mooij (1994: 7) draws a distinction between international, multinational, global, transnational and supranational marketing. When considering the translation of advertisements, we are primarily concerned with global marketing, which seeks to integrate international marketing, namely the extension of the home country marketing plan to other markets and multinational marketing where each country develops its own strategy to respond to the unique market conditions in that country. 
Global marketing therefore is based on the perception of similarities as well as differences in markets and the strategy has been summed up in the slogan "Think global, act local." In other words, the synergies and cost savings arising from an international approach are evaluated in terms of whether the approach will find acceptance outside the home market. Where this is the case it can be adopted, as we find in the practice of some multinational companies' advertising in the EU despite its cultural heterogeneity. In other cases, translation may be called for as one of the forms of adaptation.

Nevertheless, the earlier trend towards a homogeneous, international marketing approach in all markets has lost much of its appeal as companies have realised that imposing a single strategy may have an adverse effect. ${ }^{1}$ Most advertising agencies maintain offices in many countries to ensure that local cultural preferences are taken into account. Furthermore, in a more recent publication, De Mooij indicates that despite an increasing convergence of income levels in the EU, cultural values in the various member states remain stable and she predicts that the expression of these values will become more manifest in terms of purchasing choices as affluence spreads (De Mooij 2001: 22).

\section{Cross-Cultural Strategies in Practice}

Despite this apparent sensitivity to local cultural preferences, anyone who travels the world will have experienced a feeling of déja-vu when watching TV ads, or browsing in foreign-language magazines, since a great deal of advertising material is standardised and reaches members of other cultures more or less unfiltered: Procter \& Gamble, Unilever, L'Oréal and Danone (Dannon) are examples of companies which often use a global strategy. In such cases, it has been observed that global advertising campaigns retain visual material, particularly in the case of TV advertisements where high costs of filming are involved, but change the written or spoken text for a new market (Smith and Klein-Braley 1997: 183, Smith 1998: 240). There are two main strategies for dealing with visual material in this case, avoiding the need for adaptation: either neutralise the context of the advertisement in terms of landscape features and ethnicity of actors, or exploit the country-of-origin effect and its assumed positive associations (Kelly-Holmes 2005: 29).

Recently, the French carmaker, Peugeot, ran two campaigns virtually unchanged in the British and Austrian markets, and probably in other European markets as well, employing different methods to neutralise the geographical context of the visual. One was set in the US, where the sleek, sophisticated styling of the Peugeot stood out against the more functional, childlike design of the other cars on the highway. This avoided problems in EU markets, such as whether left-hand or right-hand drive vehicles should be selected, or which side of the road they should drive on. The second was filmed as a black-and-white cartoon with cars being driven in fantasy landscapes, where the context of the driving conditions was equally irrelevant. Both campaigns concentrated on the visual, which was underscored by evocative music, to the virtual exclusion of written language, thus reducing the need for translation to the final screen shot with the name of the model and the slogan. These campaigns worked in the two European countries where I saw them because the images were dislocated from the cultures in which they were shown, leaving no culture-specific elements to jar on the viewers. 
A different example of neutralisation shows that by using techniques of framing and foregrounding, commercials can be customised for international audiences. Valdés (2000: 278) describes a campaign for Orbit chewing gum with a single marketing concept, but with two film versions, an English-language one and a Spanishlanguage one. Two couples, one fair-haired and one dark-haired, are seen together at a funfair, having a good time. The funfair setting with standard rides is one which is recognisable throughout the world, so no specific cultural associations are involved. The two versions of the advertisement are ostensibly similar. Subtle changes were made in the camera angle and framing of the subjects, however, which led to the fair-haired couple being the focus in the English version and the dark-haired couple the focus of the Spanish version.

Examples of the country-of-origin effect abound in particular product categories: German companies are more likely to emphasise their origin when selling fast cars (Mercedes, BMW) than cosmetics (Nivea), whereas the majority of exclusive perfumes emanate from Paris, whether they were concocted there or not (Kelly-Holmes 2005: 35).

These two general principles of global advertising and their significance for consumers are underlined by research undertaken in France into the acceptance of TV commercials by the viewing public (Wells et al. 1992: 685). It showed that commercials produced too closely to a local market do not travel well: precisely those features which make a message recognisable for local consumers make it difficult for viewers outside that market to appreciate the ad. The picture of a bathroom containing a washing machine in an advertisement for a newly-merged German utility struck an odd note when printed in a British magazine, as the kitchen is the favoured location for washing machines in Britain. No doubt neither location would look right in other cultures.

In any campaign, a distinction has to be made between the concept and the execution of that concept. Both the idea itself and the media realisation have to strike the right note. In a comparison of British and US advertisements, De Mooij points out that British advertising makes "frequent use of features inherent in British culture, such as the persistence of class divisions and affection for eccentricity, and often employs understated humour" (1994: 239) which all serve to make the advertising unintelligible to non-Britons, including Americans, who share the same language. So can global advertising really be made to work? In the study by the French agency, Ipsos, cited above, the top 87 commercials from France, Germany, Holland, Spain, Italy and UK were judged for the likeability and conviction of their execution by 100 consumers from each country. Each of the commercials had been translated and there was an additional explanation at the end. Of the 87 commercials only three, all of which were entertaining, action-packed films, scored highly across all six countries. The key factors for the success of the top three commercials in this study were found to be the strength of the emotional appeal, entertainment value and the simplicity of the human situations shown.

Other execution problems arise when cultural taboos, such as those connected with social roles and sexuality, are at stake. Leppälä (1999: 130) reproduces a European advertisement for the male perfume, Drakkar Noir, showing a male hand clutching the perfume bottle. The bare male wrist is in turn aggressively clasped by a female hand. According to Leppälä, the version for Arab countries is toned down, and lacks this element of female aggression. It still shows the male hand holding the 
bottle, but the wrist is covered by the sleeve of a dark suit, and the female hand in this version merely strokes the male hand gently.

The evidence in this section of the paper can be summed up as follows: despite a certain degree of autonomy in local markets, there are still companies which adopt global strategies. If a global strategy is to be pursued, however, advertisers must take care to avoid any feature that would narrow its appeal to a single local audience. As far as possible, the message should be encoded non-verbally. Cultural features, including the landscape and the physical appearance of the actors, must be downplayed so that they cannot be pinned down to a particular market. There are two exceptions to this statement: if the cultural origin of the product is a part of the marketing concept, for example, it underlines its prestige, exclusivity or exoticism, then these cultural attributes should be highlighted (cf. Smith and Klein-Braley 1997: 182). Further, the multi-racial diversity in some markets allows a strategy of inclusion of people from as many races as are deemed necessary for consumers to identify with. Proctor \& Gamble, for example, features women and babies of different ethnic origins in advertisements for Dove and Pampers products. The Dove advertisements have even been praised for showing women who do not conform to the usual media-dictated ideal of thinness and youth. Shell has run a campaign showing individuals from different countries endorsing Shell's contribution to renewable energy, signalling that energy and the future of the planet are everybody's concerns. This espousal of a multi-racial ethos is not without problems, however. It leads to what Solomos and Back have criticised as a "corporate multiculturalism that trades on images of human diversity in order to produce an aesthetic that satisfies and appeals to a global market" (1996: 190), without actually doing anything to confront inequality. ${ }^{2}$

According to the French study, a further key factor for success, across Western European markets at least, is an entertaining creative idea. One of the stable features that advertisers frequently exploit for humorous purposes is the existence of cultural stereotypes (De Mooij 1994: 495-496). These are deliberately invoked to provide instant recognition of the content of the message and to increase the entertainment value of the spot. A recent campaign by the Danish Dairy Marketing Board for Lurpak butter with a strong, but simple narrative line is a case in point.

The campaign combines humour, without being too eccentric, with an interesting and accessible story line. The first commercial shows a young and beautiful, dark-haired woman arriving in a Danish town to set up a bakery. Without knowing exactly, but drawing on our stereotypical/Western European knowledge of the world, and directed by the sign she puts up in her shop window - Maria's bakery - we assume she is Italian. We see her in two further commercials as she gradually wins over the local population. In time, the locals start to indulge themselves with buttery treats and Maria is seen having to restock her fridge with more and more Lurpak butter. The language is English but everyone speaks with an obvious foreign accent. Maria represents a stereotype of Italian female eroticism, introducing an exotic element into the plain, everyday, working life of the town with her low-cut blouse and sexy voice. However, her manner is sober and she is hard-working enough for her to gain acceptance in the community, particularly among the middle-aged women. Hence the message she brings, "a life without pleasure is only half a life" is taken to heart by the local women, reminding them that they have been missing out on sensual pleasures (as well as generous servings of butter) for years. 
A detailed analysis of this campaign is not possible here, but it should be clear that here we have a potential case for adaptation in some markets but not others. A translation of the visual (re-filming or re-framing) is not necessary as the humour is based on stereotypes of homely versus glamorous women, encoded here as middleaged Danes and a young Italian. The setting and social behaviour of the actors could easily be retained. The dialogue could be dubbed, maintaining the jokey foreign accents, with no loss of effect because the wry charm of the campaign lies in the incongruity of a situation where these two contrasting worlds come together. The stereotypes of the serious, down-to-earth Danish matrons and the erotic Italian bakery owner may have been overdrawn, but the juxtaposition of the two represents exactly the kind of easily recognisable simple human situation which was advocated for global advertising above. Nevertheless, it is questionable whether the cultural allusions of this campaign could be transferred to Asian, let alone Arab, markets. ${ }^{3}$

\section{Lifestyle Strategies}

One of the factors that would appear to play into the hands of global advertisers is the emergence of lifestyle products, which are not tied to any particular national market but are bought world-wide as signs of membership of a particular social group. Social identity in this case overrides any other identities when it comes to making purchasing decisions. In the past, businessmen formed the most important group of consumers in this sector, having similar needs, e.g., for gadgets like mobile phones or laptops to allow them to work out of the office, and for transport and hotel accommodation while on the road. Lifestyle markets have developed considerably, and currently the focal point has shifted from the professional scene to the broaderbased arena of leisure pursuits as greater numbers of people have more time and disposable income to spare. Lifestyles influence consumption in unexpected ways as they are largely consumer-driven and to a certain extent impervious to external intervention. Although what are usually considered as the main global lifestyle brands, such as Coca Cola, Disney, McDonald's, etc., have been fairly stable for years, we now see the emergence of cult brands, e.g., in clothing, mobile phones, entertainment, which are not intended to appeal to the masses but to "passionate consumers [who] want their brands to become a form of self-expression" (Brady 2004: 46). It is paradoxical that, though cult brands may appear to have a minority appeal, the companies that produce them are hard at work nurturing them so they can stretch across the world to other like-minded consumers wherever they may live.

Cult brands and lifestyle brands share the following characteristics: they are more expensive than other brands which could objectively fulfil a similar function, they are exclusive, partly because of their high price, but also because they are often sold as limited editions and guarded as far as possible by their makers against counterfeiters' attempts to encroach on the market. The key attribute of a cult brand is the emotional response it can engender in the consumer, leading to identification with the brand. The advertising for these products focuses on the

product-user relationship and the depiction of scenes of consumption which emphasise its experiential aspect. [...] There has been a shift from an emphatically rational mode of argumentation supported by essentially falsifiable 'evidence' of product utility towards representations of the satisfaction that comes with using the product (Falk 1997: 68). 
The advertising, in other words, is geared to the creation and maintenance of an emotional attachment. This is crucial as cult brand consumers are both fickle and vocal, the latter meaning that they no longer keep their disappointment or frustration about products to themselves, but broadcast it widely via internet blogs, etc.

Probably the most important strategy for creating an emotional attachment is use of visual imagery and, in those media that support it, sound imagery. ${ }^{4}$ Visual images are polysemous and encourage multiple interpretations by the audience to uncover the meaning. This will be dealt with in more detail in the next section. Recent research has shown that the power of sound to create mental associations should not be underestimated, either. Radio spots employing special sound effects (including noises off, music and voice quality as well as an image-creating evocative content in the verbal message itself) to activate visual associations were better remembered than those spots executed without these techniques (Bolls and Potter 1998).

\section{Decoding the Visual}

Much of the significance of advertising messages lies in the connotations they can trigger, and, as the many advertisements without much written text amply show, the visual plays a key role in setting off a stream of associations. In his well-known analysis of the signification system in a Panzani advertisement, Barthes (1977: 34) claimed that the Italianicity of the advertisement was achieved by the paradigmatic choice of certain objects and their juxtaposition. Apart from the Panzani pasta, sauce and packet of Parmesan cheese, it is the tomatoes and peppers, as opposed to say, potatoes and carrots, bulging out of the string shopping bag, that together combine to create the signification of an Italian meal. This is further underlined by the use of the colours, red, white and green, which remind us of the Italian flag. Barthes claimed this Italianicity was French, inasmuch as no Italian would perceive Italianicity in the product name, nor associate Italianicity with a tomato or a pepper. Nevertheless, he made it clear that this Italianicity was not restricted to a French audience: even in other cultures it could be read as the condensed essence of everything which can be considered Italian, contrasting paradigmatically with other -icities, such as Frenchicity or Germanicity.

It is important to note the number of cues pointing to this interpretation: the connotative potential of this advertisement is not restricted to a single item. This factor helps to ensure recognition across a wide, possibly disparate audience. At the same time, other positive interpretations which might come to mind in conjunction with the Panzani ad, such as straight-from-the-market or just-like-home-cooking are not blocked. Beasley and Danesi speak in this context of connotative chains and claim that "the higher the number of connotative chains generated, the greater is the likelihood that the product will appeal to consumers" (2002: 109), since the consumers will be able to select their preferred interpretations from a range of possibilities.

One of the great unknowns in advertising, however, is whether the cultural and semiotic analyses undertaken by the academic community coincide with the consumers' perceptions of the advertisement (Nava 1997: 43), and whether it is even possible for consumers to take in the whole information. According to Kroeber-Riel (1993: 55), one of the problems in print advertisements lies in the information surplus they contain. He illustrates this problem with an advertisement for KLM's Business Class. 
Though the advertisement as a whole, including quite an extensive written text, contains a hundred information units, Kroeber-Riel claims that, for the average reader, only six eye fixations, taking about two seconds, are necessary to read the advertisement. In contrast, it takes about forty seconds to receive the full information. For this reason, he advocates greater use of illustrations as they allow better direct access to our internal visual memories. The idea is that subconscious responses, even to irrelevant illustrations, can forge affective relationships to products (cited in Keller 1999: 107).

The evidence in this section points strongly in favour of the visual element in ads on account of its capacity to attract the attention of the viewer as well as encode multiple messages, which may or may not be retrieved by the viewer. From an academic point of view, one of the drawbacks of visual messages is the subjectivity of the interpretations, so the "real meaning may be different from the individual reading that a particular person may produce" (Slater 1998: 243). This may not be important in advertising, however, as, in terms of post-structuralist semiotic analysis, "the constitution of contradictory subject positions within contradictory texts" (Slater 1998: 244) may enhance the viewers' ability to express their social identity (Messaris 1996: 117). In any case, advertisements are increasingly subverted by young people, who see them as forms of entertainment, and may well disregard the product message. As O'Donohoe found in her study of young adults' responses to advertising:

this study paints a picture of young adults as active, sophisticated and ambivalent consumers of advertising. They communicated a sense of enjoyment and ennui with respect to advertising, and appeared to feel both immune and vulnerable to its persuasive power (1997: 271-272).

If visual images are polysemous, are they universally interpretable? As the case study will show later, there is considerable overlap in the execution of campaigns in Western European and Asian countries, even to the extent of merely reproducing a Western campaign, but it remains unclear whether this is a successful strategy. As already indicated, divergent readings of a polysemous advertisement may not be a problem, if, as O'Donohoe's study showed, the viewers at least retain a memory trace of the brand name, which can be activated later. An M.A. thesis on cross-cultural interpretations of advertisements by Anne Dumas, cited in Messaris 1996, may help to clarify this question.

In this study, the responses to advertisements by recent immigrants to the US from China were compared with those of US-born students. The illustrations showed various interpersonal relationships, such as a father and son sharing a joke, a homecoming soldier embracing a woman, a father playing with a child. The Chinese respondents stated that the scenes represented in the pictures were not part of their own personal experience, and that their interpretations were merely conjectures of what the relationships might be. They claimed many of the relationships shown diverged strongly from Chinese cultural norms, particularly the depiction of the father as a friend, rather than as an authority to be respected. The illustrations of fond, family relationships were appreciated by the Chinese respondents even though they said they were remote from their own experience. As a result, there turned out to be a fairly close correspondence with the US students' responses. What the Chinese students routinely failed to recognise was an aspect of cultural socialisation, namely the display of social status. They interpreted, for example, jeans as a sign of working- 
class attire, instead of up-scale, yuppie clothing. The findings of this study confirm some of the positions stated in Section 3: there are certain communalities in terms of human experience which need no further explanation across cultures. The human body, emotions and one's passage through life are recognised in all cultures, even if the rituals connected with them differ.

This indicates that, in terms of global advertising, the advertising concept and the means of execution must be assessed separately for their viability in different markets. However, it does not mean that cultural differences are an impediment for advertisers. Messaris (1996: 111) reports a research finding that though French advertisements contain more sexual appeals than US ads, this does not mean that US consumers are unresponsive to this kind of advertising. Such a finding, however, has to be seen in relation to the particular product being promoted and the demographic make-up of the section of the market being addressed by this type of appeal. It is important to remember in discussions about responses to advertisements that ignorance of cultural differences may be interpreted as arrogance on the part of the company selling the product and a lack of respect for the potential consumer, thus provoking a strong negative backlash and feeling of resentment.

\section{Visual design}

In this section I summarise the work of Kress and Van Leeuwen on the organisation of print advertisements, without claiming to do justice to the complexity of their analytical framework. While the Gutenberg diagonal, an imaginary line drawn from the top left-hand corner of a page down to the bottom right-hand corner, has long figured as an organising principle for graphic designers preparing layouts in Western advertisements, Kress and Van Leeuwen (1996) have applied insights from linguistics to the field of visual design to show that layout is part of the overall communication and is significant in itself.

For the present discussion, the main categories in this framework are the division of the page into top and bottom, left and right, and margin and centre. These parts are awarded varying prominence in page layouts. In many advertisements the top of the page, which may actually be $90-100 \%$ of the page, is taken up by the illustration and represents the ideal of the ad (also called the promise). The lower part represents the real and this is conveyed by any text message the ad may contain. Another layout format is the given and new organisation of left and right, in analogy with sentence and text grammars. The known information, shown on the left, is assumed to be seen first in Western cultures, whereas the new information is on the right. A further distinction is drawn between the margins and the centre. This organisation can create an order of symmetry rather than the potential antagonism or polarisation found in top-down, left-right formats. Kress and Van Leeuwen (1996: 206) remind us that this is the way children's drawings are constructed, but point out that centre-margin visualisation is rare in Western painting, in contrast to its use in Asian design. They speculate that this relates to a Confucian tradition in these countries. Scollon and Scollon give examples of how this works in practice in restaurant signs in China, which often use a triptych organisation. A central section gives the name, comparable to the ideal, and this is flanked on the left and right by information on the restaurant's specialities, the real $(2003: 5,92)$. 
The left-right organisation, of course, is limited to those cultures where the writing system moves from left to right and hence does not apply to Arabic and Ivrit. Smith (1998: 241) gives the example of an advertisement for a headache medication promising fast relief, which was translated into Arabic. Unfortunately the accompanying three illustrations indicating before, during and after taking the tablet were not reversed, leaving the readers to believe they would be in greater pain after taking it. Van Leeuwen (2005: 202) claims that the left-right pattern is also reversed in Chinese, but the situation in China is not quite so clear-cut, as the case study will show.

There has been little research into the implications of layout or choice of fonts in the translation of advertisements, but it is clear that advertisers exploit layout to impose their preferred reading path through the advertisement. Séguinot (1994: 253) shows the problems arising from text translation where the source and target versions take up different amounts of space, and warns translators about the sometimes arbitrary allocation of white space by graphics specialists which breaks up units of text and leaves an incoherent message. It is important to note that typographical features can sometimes be part of the overall visual message, for example, the choice of handwriting instead of a print font, a few Cyrillic letters to evoke Slav connotations, and so on. What is not clear is how or whether such messages are understood in a different culture.

\section{A Case Study - China}

China has only recently seen the rise of a middle class with spending power and so Western-style advertising is a relatively new phenomenon. At a time when other world markets are stable or stagnating, it is not only the size of the market but also the rapid increase in affluence in some sectors of the community that attract global advertising. According to Lai Man So (2002: 38), the advertising market in China was dominated by multinational advertisers in the $90 \mathrm{~s}$, but now local agencies are increasing their presence. The Chinese market is far from being uniform: the big cities of Shanghai, Beijing and Guangdong account for 50\% of ad spending, but only $8 \%$ of the population (Lai Man So 2002: 34), so there is clearly scope for development. Particularly producers of high-priced, luxury goods are targeting China with the aim of establishing brand recognition as well as selling their products. This strategy represents a long-term investment, but does have a short-term benefit: as more and more Chinese tourists travel abroad, they will hopefully choose familiar, exclusive brands when they go shopping. Full-length studies of Chinese advertising are thin on the ground as yet, but some of the works cited so far make passing references to China. These findings will now be summarised and further illustrated with a corpus of advertisements ${ }^{5}$ from Chinese print media and websites.

In his study on visual metaphor in advertising, Forceville (1996) asked an international group of participants attending a conference to describe the illustrations on three billboards in their own words and then recount their personal feelings and associations. The billboards in question, representing different visual metaphors, were advertisements for IBM, but without any text apart from the IBM logo. Although the participants generally confirmed Forceville's hypothesis that the metaphorical qualities of the billboards' illustrations would be recognised, one participant, a 
Chinese lady, gave strongly divergent answers and was the only respondent unable to identify the product. Forceville speculates that she was unfamiliar with the Western cultural code and might be "confused about the aims and objectives of commercial advertising" (1996: 193). Although this evidence is from just one participant, he suggests that pictures may not cross borders more easily than words and that the interpretation of pictures may presuppose considerable cultural background knowledge. ${ }^{6}$ In a similar vein, Myers points out that the audiences for an advertisement "are formed over time as people encounter and transform the texts" (1994: 197). Forceville's interpretation may have been limited by the aims of his study, but there is a certain degree of convergence with the findings of the Chinese study described in Section 5. Both point to the difficulty the Chinese respondents faced when trying to rationalise what images originating in a different system of cultural conventions meant, even though their emotional responses to images were quite similar to the responses by the Western respondents.

According to Kress and Van Leeuwen (1996: 186-192), the layout of magazines and advertisements in Western space-based semiotic modes uses a left-right organisation for Given and New information. Van Leeuwen claims that this layout scheme is reversed in Chinese publications (2005: 202, also De Mooij 1994: 257). Van Leeuwen gives the example of advertisements for slimming products in Western publications with a before model occupying the left-hand space and the slimmed down after model occupying the right-hand space. According to Van Leeuwen, in Chinese advertisements, the before picture is on the right and the after on the left. This, however, is not the case in my corpus, which contains slimming product, baldness treatment and scar removal advertisements, all of which conform to the Western pattern. Granted I have only five items as evidence for this statement, but none which provide counter-evidence to support Van Leeuwen's hypothesis.

De Mooij (1994: 132) identifies further factors as relevant for the Chinese market: China, like other Asian countries, is a high-context culture (cf. Hall 1976). Characteristic of high-context cultures are implicit communication codes, favouring what is unsaid, and non-verbal communication. In any case, with adult literacy at $83 \%$ (Economist 2001: 124), advertisements with a good visual presentation would appear to have an advantage. Great value is attached to group identity and collective cultural elements: any humorous appeals should focus on large groups rather than individuals. A further concern is the use of faces: De Mooij (1994: 132) cites a research finding that the use of foreign faces in addressing Chinese consumers is considered ineffective. The use of foreign faces is advisable only for products, such as Coca Cola, when the company wants to represent itself as a foreign brand. The selection of faces is further complicated by the sheer size of China, where people from different regions also look quite different. For a pan-China campaign, De Mooij advocates selecting "generic looking" actors (1994: 256).

My corpus of 35 Chinese advertisements consists largely of ads for cosmetic products and some luxury goods. The luxury goods e.g., for Louis Vuitton, Prada and Gucci bags, for Swatch and Omega watches and for Chanel Chance perfume can be dealt with quite easily as they are advertised in the same way as in European publications, using the same artwork, with little recourse to text. Gucci uses the brand name as a text, while Louis Vuitton dispenses with text entirely, if one ignores the characteristic LV-logo pattern on the bag. The others use Chinese texts, read from 
left to right, apart from Swatch, which additionally uses the traditional top-down orthography. The layouts have not been changed from the formats seen in Western magazines and billboards.

The advertisements for cosmetic products fall into two main categories, single and double-page spreads. This makes a difference in terms of formatting as the illustration of the product's promise (Kress and Van Leeuwen 1996: 184) in a single page advertisement is placed in the top half or two-thirds of the page, the ideal space in Kress and Van Leeuwen's terminology. All of the single page advertisements conform to this principle, though sometimes the illustration takes up the whole page. The picture of the product itself or the product name, including the logo, is in the bottom right-hand corner. The explanatory text is along the bottom margin. The direction of the model's gaze or face, where a model is used, is towards the right, imposing a reading path from the top-left to the bottom-right. None of the layouts of these advertisements differs from the standard Western pattern, although some of them, using Chinese models (Nivea, Olay), have obviously been created specially for the Chinese market.

The situation is slightly different with the double-page spreads. In the majority of advertisements the typical Western pattern is used - with the picture of the model on the left-hand page and the picture of the product package and the explanatory text on the right. An unusual feature in two of these advertisements is the direction of gaze. Rather than looking at the viewer or directing their gaze towards the text and product picture on the right-hand page, these models are looking beyond the frame of the advertisement towards the left, turning their backs, so to speak, on the product. ${ }^{7}$ There is greater use of Chinese models (Biotherm Homme, Olay, Pantene, Estée Lauder, Amway), although a number of advertisements have retained their Western artwork. Strangely, Estée Lauder uses both Western and Chinese models, even though they advertise two skin-whitening products which are not available in Western markets. ${ }^{8}$ This maybe an attempt to capitalise on the two conflicting goals of the desirability and attainability of this white facial appearance. Three advertisements reverse the order of presentation, i.e., model on the right, product and text on the left, confirming Van Leeuwen's predictions of Chinese layouts. These advertisements for Max Factor, Dior and Estée Lauder products, however, used a Western model for this layout. It would appear that the marketing department of Estée Lauder is either hedging its bets or has no particular strategy.

An advertisement for Lurpak butter (see appendix) shows how East and West meet in an advertisement and how a relatively unknown product and its consumption is positioned in the Chinese market. A young couple is pictured at breakfast. The young woman, dressed in a pale pink satin robe is being tempted to eat a slice of bread/toast, spread with butter, by the young man standing behind her. He is wearing a sleeveless undershirt and pants. She is seated at a table, though too high to comfortably put her legs under it, and the table is laid with a basket filled with sliced bread and a plate with curls of butter. Her seating position allows the faces of the two models to come close together without the man contorting himself too much. The whole scene, including the background, is photographed in soft pastel tones of pink and pale blue creating a harmonious effect. The only contrasts are the two Chinese models' dark hair and the text below the picture in black characters. Here butter is presented with an erotic appeal as a luxury, young person's product, while at the same 
time a suggestion for how it can be eaten in a meal is given, since bread and butter is not part of the standard Chinese breakfast. The layout follows the Gutenberg diagonal scheme with an implied reading path from the top-left to the bottom right of the page. This advertisement was judged to be highly attractive by a small, unrepresentative sample of Chinese students from my university. Like the Chinese respondent in Forceville's study, they particularly appreciated the harmony of the colours. They also liked the way the couple were depicted and did not notice anything anomalous about the layout.

It is not possible to go into further examples from the corpus in detail, but some conclusions may be drawn. The advertising for luxury goods in China is far more varied than previous studies would lead us to believe in terms of layout, facial types and the preference for group values. The question of whether images representing group rather than individual identities are preferred cannot be answered, as, apart from the couple shown in the butter advertisement, only individual figures are shown. It is conceivable, however, that the type of product and influence of international advertising agencies, mentioned at the beginning of this case study, has distorted the nature of the advertisements in this category of advertising and that there will be further shifts as Chinese agencies gain ground. On this evidence, there is little sign that advertisements have been localised: the preference for Chinese faces was evident in only a third of the advertisements. However, the before/after slimming, baldness and scar advertisements used exclusively Chinese models. This is probably a wise strategy as it results in stronger consumer identification, showing that ordinary people can benefit from such treatments, and not just glamorous models. The avoidance of Chinese models in the luxury cosmetics advertisements could be interpreted as an indication that some companies are still testing the market and are not yet prepared to make a full investment in localised advertising, or merely exploiting their Western origin. As advertising expands in China, we can expect greater diversity in advertising formats and more work on consumer responses to advertisements emanating from China itself.

\section{Conclusion}

The question of translating the visual is one which is currently under-researched. In this article I have avoided a tips-and-tricks approach as this topic requires a careful consideration of all the complex issues involved in each individual case. Instead I have presented a cross-section of recent studies on the visual as a cultural and social concept. Where possible, I have related the findings of these studies to themes relevant to the perception of advertisements in different cultures. One of the key insights from cultural studies is that responses to the visual are based on potentially contradictory subjective positions. This explains both people's enjoyment of and disaffection with advertising. At the same time it has been found that, despite the existence of tacit or overt cultural conventions limiting what can be depicted in what ways, there are deep-seated human values which appear to cut across cultural barriers, permitting a level of common understanding despite differences in conventional presentations.

There are a number of factors which make the involvement of translators in the creation and adaptation of global advertisements desirable. First and foremost is their detailed knowledge of cultures and changes in the cultural landscapes relating to the 
language pairs they work with. Second, for many translators, comes their experience of dealing with illustration and issues of layout e.g., in technical texts, tourist brochures, etc. This involves a competence in visual organisation, which can be drawn on for the task of judging the appropriateness of visual configurations, even if the scope for direct intervention may be limited.

Nevertheless, the translator's role in adapting visual messages in advertisements may well be restricted to particular marketing and PR formats, in particular to Website localisation. In TV and magazine advertising there are a number of product categories which rely exclusively on the power of the visual to evoke an emotional response. Many of the visuals are unrelated to the product but operate on a subconscious level. Many are even designed to present a challenge to the viewers, forcing them engage in deep level cognitive processing in order to create a link between the advertisement and the product. Such visuals are, of course, resistant to adaptation. According to Gimein, this trend towards indirect messages stems from a growing distrust of advertisements and will increase in the future:

ads can't tell viewers about products anymore, because nobody trusts what they say about products, so they're free to be just really good ads. And our willingness to buy products becomes a sort of referendum on the commercials. Bet on the trend continuing, with tomorrow's advertising becoming increasingly Zen-like in its abstention from any connection with products (2002: 36$)$.

With Web advertising the situation is different: the marketing strategy shifts away from mass media to more direct contact with consumers. Here there would appear to be scope for the translator's cross-cultural expertise to be utilised. Although Czinkota and Ronkainen (2001: 628) advocate similarity in the look of localised websites across the different language used, this view is questioned by Nantel and Glaser in their study of multicultural websites. The Francophone and Anglophone Canadian respondents in their study gave higher scores on usability to the site which was originally conceived in their native language. In terms of the quality of offer, there was no significant difference in the two groups' perception of the sites. Nantel and Glaser conclude that mere translation of the verbal message is not a satisfactory solution to the localisation problem: the overall design may also have to be changed (Nantel and Glaser 2005). The results of this study show that, even in cultures where the cultural distance is assumed to be fairly small, usability can be affected by inadequate localisation measures.

One thing is certain: whoever feels tempted to specialise in working on multimodal texts in the field of advertising will have to bring a strong commitment to a line of work which goes beyond the translator's usual competence and requires the ability to respond to trends rapidly, before they have fizzled out.

\section{NOTES}

1. The product positioning, for example, may vary in different markets. Parker Pens discovered that a centralised campaign was impossible as its pens were viewed as prestige writing instruments in some markets, but as functional tools in others (Czinkota and Ronkainen 2001: 686).

2. Cf. Nicoletta Vasta's (2005) critical analysis of another Shell campaign Profits and Principles - Does there Have to Be a Choice? in which she demonstrates how the African people depicted as the most salient subjects in one ad are reduced to mere types as opposed to genuine acting subjects - in grotesque contrast to the verbal message of community investment Shell claims to be making in the ad. 
3. These ads can be viewed on www.lurpak.com Apart from the UK, Saudi Arabia is an important market. For obvious reasons, this campaign is not used there. The Danish Dairy Marketing Board has produced an alternative campaign for this market, using the slogan "spoil yourself with Lurpak" instead of the deliberately ambiguous "give in to Lurpak." The execution of the concept is again entertaining, but uses a different type of humour and an all-male cast (apart from the cow).

4. The other strategy for cult brands is to develop an emotional relationship by building a brand community. Harley-Davidson is a classic example of this approach. Although the brand is advertised in motorcycle magazines, the main advertising thrust comes from the Harley Owners' Group, which is sponsored by the company, but driven by the members themselves. When brands achieve this level of identification, they can rely on the proselytising effect of their consumers talking to their friends, or setting up their own websites for the brand. This latter development would appear to lessen the companies' role in propagating the message, but this is not the case. Companies still have to ensure their brands are clearly differentiated from rivals' and continue to ensure there is a buzz around their products by observing trends and "reinforcing lifestyle behaviors already present" (Danesi 1999: 185).

5. I am indebted to Chen Hong and Tatjana Wright for their help in assembling and interpreting the corpus of advertising material used in this case study.

6. This phenomenon has been observed in cognitive metaphor research: there are a number of conceptual metaphors which appear to be universal at the generic level, e.g., metaphors for emotions. However, variation can occur both cross-culturally and within cultures at the specific level (cf. Kövecses 2002). This means that particular instantiations of a conceptual metaphor may not be recognised in a different cultural context.

7. This might relate to what Erving Goffman termed "psychological or licensed withdrawal" in women's posing in ads (cf. Frith and Mueller 2003: 230). However, it can also be observed in a Huawei Technologies print campaign with men as models, looking out beyond the frame of the ad, accessible under <www.huawei.com $>$.

8. This is an important cultural difference: the traditional Chinese ideal of beauty is for white skin (cf. Prasso 2005: 52). Even the body skin of the Chinese model for Nivea Sun Spray SPF 20 is considerably lighter than the bronzed skin of the model in an equivalent Nivea Sun advertisement found in the Russian version of Cosmopolitan.

\section{REFERENCES}

Barthes, R. (1977): Image Music Text, London, Fontana.

Beasley, R. and M. Danesi (2002): Persuasive Signs. The Semiotics of Advertising, Berlin/New York, Mouton de Gruyter.

Bolls, P. D. and R. F. Potter (1998): "I Saw it on the Radio: The Effects of Imagery-Evoking Radio Commercials on Listeners Allocation of Attention and Attitude Towards the Ad," in Meuhling, D. D. (ed.), Proceedings of the 1998 Conference of the American Academy of Advertising, Pullman, Washington State University, pp. 123-130.

Brady, D. (2004): “Cult Brands,” Business Week August 9, pp. 46-49.

Czinkota, M. R. and I. A Ronkainen (2001): International Marketing, Fort Worth/Philadelphia, Harcourt College Publishers.

DAnesi, M. (1999): Of Cigarettes, High Heels, and Other Interesting Things, Houndmills/London, Macmillan.

De Moorj, M. (1994): Advertising Worldwide. Concepts, Theories and Practice of International, Multinational and Global Advertising, New York/London, Prentice Hall.

De Moorj, M. (2001): “The Impact of Culture on Advertising," in KLoss, I. (ed.), Advertising Worldwide, Berlin/New York, Springer, pp. 1-24.

FALK, P. (1997): "The Benetton-Toscani Effect. Testing the Limits of Conventional Advertising," in Nava, M., Blake, A., MacRury, I. and B. Richards (eds.), Buy This Book. Studies in Advertising and Consumption, London/New York, Routledge, pp. 64-83.

Forceville, C. (1996): Pictorial Metaphor in Advertising, London/New York, Routledge.

Frith, K. T. and B. Mueller (2003): Advertising and Societies. Global Issues, New York/Washington/Baltimore, Peter Lang. 
Gimein, M. (2002): “Program-Free Commercials,” Fortune, April 1, p. 36.

Hall, E. T. (1976): Beyond Culture, New York, Doubleday.

Jakobson, R. (1959/2000): “On Linguistic Aspects of Translation," in Venuti, L. (ed.), The Translation Studies Reader, London/New York, Routledge, pp. 113-118.

Keller, R. (1999): "Interkulturelle Marketingkommunikation in Theorie und Praxis," in Bungarten, T. (Hg.), Sprache und Kultur in der interkulturellen Marketingkommunikation, Tostedt, Attikon Verlag, pp. 106-112.

Kelly-Holmes, H. (2005): Advertising as Multilingual Communication, Houndmills/New York, Palgrave Macmillan.

Kövecses, Z. (2002): Metaphor. A Practical Introduction, Oxford, Oxford University Press.

Kress, G. and T. van LeEuwen (1996): Reading Images. The Grammar of Visual Design, London, Routledge.

Kress, G. and C. Jewitt (2003): "Introduction," in Jewitt, C. and G. Kress (eds.), Multimodal Literacy, New York/Washington, Peter Lang, pp. 1-18.

Kroeber-Riel, W. (1993): Bildkommunikation: Imagerystrategien für die Werbung, Munich, Vahlen.

LaI Man So, S. (2002): "Advertising in China," in Kloss, I. (ed.), More Worldwide Advertising. Berlin/New York, Springer, pp. 32-63.

LeppäLÄ, K. (1999): Kulturelles Wissen in der Werbung, in Bungarten, T. (Hg.), Sprache und Kultur in der interkulturellen Marketingkommunikation, Tostedt, Attikon Verlag, pp. 126131.

Messaris, P. (1996): Visual Persuasion. The Role of Images in Advertising, Thousand Oaks/London, Sage Publications.

Morris, D. (1977): Manwatching. A Field Guide to Human Behaviour, Frogmore, Triad/Panther Books.

Myers, G. (1994): Words in Ads, London, Edward Arnold.

NAntel, J. and E. Glaser (2004): "Multicultural Commercial Websites: When translating might not be enough," in Cunningham, P. and M. Cunningham (eds.), eAdoption and the Knowledge Economy: Issues, Applications, Case Studies, Amsterdam, IOS Press, pp. 167173.

NAva, M. (1997): "Framing Advertising. Cultural Analysis and the Incrimination of Visual Texts," in Nava, M., Blake, A., MacRury, I. and B. Richards (eds.), Buy This Book. Studies in Advertising and Consumption, London/New York, Routledge, pp. 34-50.

NorD, C. (1988): Textanalyse und Übersetzen. Theoretische Grundlagen, Methode und didaktische Anwendung einer übersetzungsrelevanten Textanalyse, Heidelberg, Groos.

O’Donoнoe, S. (1997): "Leaky Boundaries: Intertextuality and Young Adult Experiences of Advertising," in Nava, M., Blake, A., MacRury, I. and B. Richards (eds.), Buy This Book. Studies in Advertising and Consumption, London/New York, Routledge, pp. 257-275.

Prasso, S. (2005): "Battle for the Face of China," Fortune, December 19, pp. 48-56.

Schröder, H. (1993): "Semiotische Aspekte multimedialer Texte," in Schröder, H. (Hrsg.) Fachtextpragmatik, Tübingen, Gunter Narr, pp. 189-213.

Scollon, R. and S. Wong SCollon (2003): Discourses In Place. Language in the Material World, London/New York, Routledge.

SÉGuinot, C. (1994): “Translation and Advertising: Going Global," Current Issues in Language and Society 1-3, pp. 249-265.

Slater, D. (1998): "Analysing Cultural Objects: Content Analysis and Semiotics," in Seale, C., Researching Society and Culture, London/Thousand Oaks, Sage, pp. 233-244.

Smith, V. and C. Klein-Braley (1997): "Advertising - A five-stage strategy for translation," in Snell-Hornby, M., Jettmarovà, Z. and K. Kaindl (eds.), Translation as Intercultural Communication. Selected Papers from the EST Congress, Prague 1995, Amsterdam/Philadelphia, John Benjamins, pp. 173-184.

Smith, V. (1998): "Werbetexte," in Snell-Hornby, M., Hönig, H. G., Kussmaul, P. and Sснмітт, P. A. (Hrsg.), Handbuch Translation, Tübingen, Stauffenburg, pp. 238-242. 
Solomos, J. and L. BAск (1996): Racism and Society, London, Macmillan.

VAlDÉs, Cristina. 2000. Translated Advertisements. In Chesterman, Andrew, Natividad San Salvador Gallardo and Yves Gambier (eds.) Translation in Context. Selected Contributions from the EST Congress, Granada, 1998. Amsterdam/Philadelphia: John Benjamins, 271280.

Van Leeuwen, T. (2005): Introducing Social Semiotics, London/New York, Routledge.

Vasta, N. (2005): “'Profits and Principles: Is there a Choice'? The Multimodal Construction of Shell's Commitment to Social Responsibility and the Environment in and across Advertising Texts," in Cortese, G. and A. Duszak (eds.), Identity, Community, Discourse. English in Intercultural Settings, Bern/Berlin, Peter Lang, pp. 429-452.

Wells, W., Burnett, J. and S. Moriarty (1992): Advertising. Principles and Practice, Englewood Cliffs, Prentice Hall.

\section{APPENDIX}

Chinese advertisement for Lurpak Butter

(by kind permission of the Danish Dairy Marketing Board).

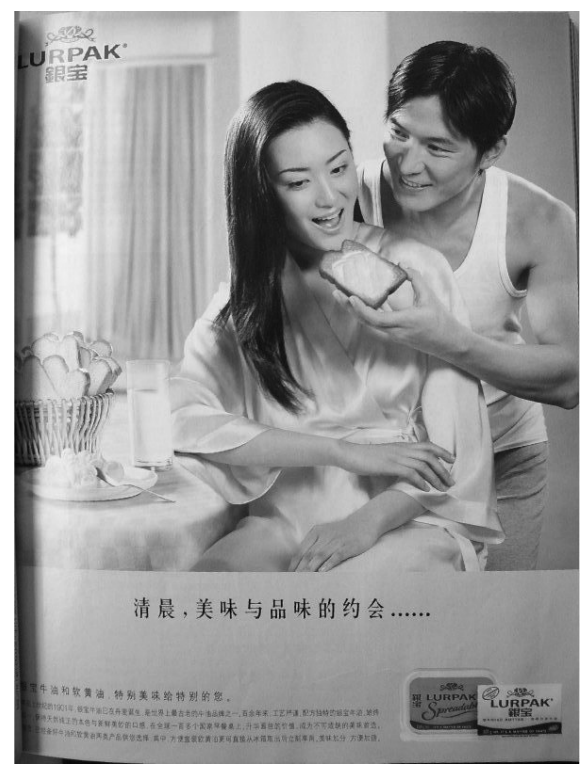

